\title{
Pendapatan Wasit dan Asisten Wasit Liga 1 Shopee 2020/2021 di Masa Pandemic Covid-19
}

\author{
League 1 Shopee 2020/2021 Referee and Assistant Referee Referees Income \\ during the Covid-19 Pandemic
}

\section{Bangbang Syamsudar}

Program studi PJKR, STKIP Pasundan, Cimahi, Jawa Barat, 40512, Indonesia

\begin{abstract}
Abstrak
Penelitian ini bertujuan untuk mengetahui pendapatan wasit Liga 1 tahun 2020 yang berdomisili didaerah Jawa Barat sebelum dan saat terjadi pandemi Covid-19. Jenis penelitian ini deskriptif dan dengan teknik penarikan sampel dilakukan secara total sampling sebanyak 10 responden yang terdiri dari 6 wasit dan 5 asisten wasit yang berasal dari Asosiasi Provinsi PSSI Jawa Barat. Pengumpulan data dilakukan melalui teknik wawancara melalui telepon dan surveyheart sedangkan analisis data dilakukan dengan teknik persentase kemudian di interpretasikan secara deskriptif. Hasil penelitian ini menunjukkan bahwa pendapatan wasit dan asisten wasit sepakbpola Liga 1 anggota Asosiasi Provinsi PSSI Jaw a Barat mengalami penurunan pada saat pandemi Covid-19.

Kata kunci : Pendapatan, Wasit, Covid-19
\end{abstract}

\begin{abstract}
This study aims to determine the income of League 1 referees in 2020 who live in the West Java area before and during the Covid-19 pandemic. This type of research is descriptive and with the sampling technique carried out by a total sampling of 10 respondents consisting of 6 referees and 5 assistant referees from the Association of West Java PSSI Provinces. The data was collected by means of telephone interviews and surveyheart techniques, while data analysis was carried out using the percentage technique and then interpreted descriptively. The results of this study indicate that the income of League 1 football referees and assistant referees of the Association of West Java PSSI Provinces has decreased during the Covid-19 pandemic.

Keywords : Income, Referee, Covid-19
\end{abstract}

\section{PENDAHULUAN}

Kesehatan merupakan hal yang menjadi skala prioritas dalam kehidupan masyarakat dunia, oleh karena itu disetiap negara yang berada dibelahan dunia menyepakati bahwa alat untuk mencegah terjadinya gangguan kesehatan adalah dengan pencegahan preventif melalui pola makan yang baik, pola istirahat, dan pola latihan olahraga yang adekuat (Prasetyo, 2015). Pola makan yang baik harus didasari dengan pengetahuan yang mumpuni dalam mengkonsumsi makanan sesuai dengan kebutuhan tubuh manusia. Selain itu perlu dilakukan program pembinaan gizi dan pengetahuan kesehatan seperti diadakannya penyuluhan, kampanye (Nia Novita Wirawan, 2017) sedangkan pola istirahat yang baik menurut National Sleep Foundation dalam lifestyle.kompas.com, (diunduh pada tanggal $17 / 11 / 2020$, pukul 10.11) untuk orang 
dewasa adalah 7-8 jam. Tidur adalah kebutuhan dasar manusia, dengan tidur semua lelah dapat berkurang dan akan kembali mendapatkan tenaga serta semangat untuk menyelesaikan persoalan yang dihadapi dalam kehidupan manusia (Ambarwati, 2017). Selain itu yang dimaksud dengan pola latihan olahraga yang adekuat adalah pola latihan yang terprogram, sistematis yang bersifat meningkatkan kebugaran fisik (Palar, Wongkar, \& Ticoalu, 2015). Beberapa manfaat berolahraga : meningkatkan daya tahan tubuh, meningkatkan fungsi otak, menghilangkan stress, menurunkan kolestrol. Keadaan kondisi yang baik akan mempengaruhi aspek-aspek kejiwaan yang berupa peningkatan motivasi kerja, semangat kerja, rasa percaya diri, ketelitian, dan lain sebagainya, hal ini menunjukkan bahwa kebugaran jasmani melalui aktivitas fisik sangat penting (Tangkudung James, 2006). Salah satu contoh olahraga sederhana yang dapat dijadikan pilihan dalam menjaga kesehatan adalah, jalan cepat,senam, renang,lari dan bersepeda (Pane, 2015). Setiap orang pasti memiliki cara masing-masing dalam menyikapi suatu masalah. Termasuk pada kondisi pandemi saat ini, banyak orang yang terpaksa harus menghadapi kondisi yang tidak seperti biasanya. Beberapa orang ada yang tetap bisa menerima dan melakukan aktivitasnya tanpa begitu masalah dimasa pandemic ini, ada pula orang yang merasa terbebani dalam menjalani keseharian dimasa pandemi ini (Nadiar \& Janitra, 2020)

Namun demikian, ketika pada masa pandemic covid-19 melanda seluruh dunia tepatnya pada bulan Desember 2019, virus corona ini mulai merebak di Wuhan, China, Desember 2019220 negara didunia terkonfirmasi positif covid-19, dengan jumlah 54.301.156 orang positif dan 1.316.994 meninggal dunia (16 November 2020, 08:59 pm, GMT+7) (https://www.covid19.go.id/), sedangkan di Indonesia kasus positif terdiri dari 470.648 orang, dinyatakan sembuh 395.443 , kemudian yang dinyatakan meninggal dunia berjumlah 15.296 orang (Update Terakhir: 16-11-2020, dari https://www.covid19.go.id/), hal dengan uraian diatas menjadi pertimbangan pemerintah daerah maupun pemerintah pusat dalam pemberlakuan kegiatan olahraga di seluruh wilayah Indonesia, khususnya dicabang olahraga sepakbola, dimana pada pelaksanaan liga 1 Shopee 2020/2021, tepatnya di Matchday ke-3 dibulan Maret 2020, dengan terpaksa dihentikan sampai pada waktu yang belum ditentukan. Keputusan pemerintah tersebut dilakukan untuk mencegah penyebaran virus yang massif, dikarenakan pada tanggal 2 Maret 2020, untuk pertama kalinya pemerintah mengumumkan dua kasus pasien positif Covid-19 di Indonesia (www.kompas.com) yang diunduh pada tanggal 17/11/2020, pukul 10:26 WIB. Selain itu, gerakan mencegah dari pada mengobati baiknya tetap diterapkan dan tidak terlambat, mengingat karena penyebaran virus ini sangat cepat dan telah banyak menelan korban 
jiwa (Zendrato, 2020). Terhitung bulan Maret sampai bulan November 2020, ketika artikel ini dibuat, kelanjutan Liga Shopee 2020/2021 belum memungkinkan untuk digelar, sehingga mengakibatkan para stakeholders seperti tim atau klub dalam hal ini melibatkan manajer, pelatih, pemain, dan ofisial kemudian perangkat pertandingan dalam hal ini Pengawas Pertandingan, Pengawas Wasit, Wasit, dan Asisten Wasit, pedagang kaki lima, pihak sponsor penonton dan yang lainnya terkena imbas mengenai pemenuhan kebutuhan ekonomi, terutama dalam hal mata pencaharian untuk memenuhi kebutuhan hidup nya. Kronologis kejadian diatas tentunya menjadi awal mula ketertarikan penulis untuk mengadakan penelitian, khususnya mengenai imbas covid-19 terhadap penghasilan wasit dan asisten wasit Liga 1 Shopee 2020/2021. Dampak yang terjadi pada perekonomian karena pandemic Covid-19 yang terjadi pada saat ini yaitu kesulitan masyarakat dalam mencari lapangan pekerjaan, tidak mempunyai penghasilan dalam memenuhi kebutuhan untuk sehari-hari, sehingga dapat disimpulkan bahwa semua sektor perekonomian dalam semua bidang juga merasakan dampak dari Covid-19,(Hanoatubun, 2020) termasuk di dunia olahraga khususnya cabang olahraga sepakbola. Di level liga 1 para pemain, pelatih, dan wasit banyak yang menggantungkan hidupnya dari setiap penampilan pertandingan di lapangan, karena mereka sudah dikategorikan menjadi bagian dunia professional, akan tetapi dengan tidak adanya kepastian lanjutan kompetisi, mengakibatkan penghasilan menjadi masalah besar bagi diri dan keluarganya. Berdasarkan uraian diatas maka dapat diambil rumusan masalah apakah ada perbedaan pendapatan wasit dan asisten wasit liga 1 Shopee 2020/2021 sebelum dan saat terjadi pandemi Covid-19 di lingkungan anggota Asosiasi Provinsi PSSI Jaw a Barat.

\section{METODE}

Metode yang digunakan dalam penelitian ini adalah metode kualitatif. Penelitian kualitatif adalah penelitian yang menghasilkan dan mengolah data yang bersifat deskriptif, seperti transkripsi dari hasil wawancara, survei dalam hal ini menggunakan aplikasi surveyheart. Metode pengumpulan data adalah data primer dengan melakukan waw ancara dan survey dengan menggunakan aplikasi surveyheart. Penelitian ini terbatas pada populasi wasit liga 1 yang tersebar di wilayah Asosiasi Provinsi PSSI Jawa Barat yang terdiri dari jumlah dengan total 11 orang sampel. Penelitian ini adalah studi kasus eksplorasi dan sampel dipilih menggunakan metode total populasi sampling.Total populasi sampling adalah jenis teknik purposive sampling yang melibatkan pemeriksaan seluruh populasi (yaitu, total populasi) yang memiliki seperangkat karakteristik tertentu misalnya, atribut / sifat tertentu, pengalaman, pengetahuan, keterampilan, paparan suatu peristiwa (Laerd Dissertation, 2012). 


\section{HASIL DAN PEMBAHASAN}

Covid-19 adalah virus yang menyebabkan gangguan ringan pada sistem pernapasan, infeksi paru-paru yang berat, hingga kematian. Di Indonesia pandemic COVID-19 yang saat ini terus mengalami eskalasi, tidak hanya berpotensi mengakibatkan kontraksi pertumbuhan ekonomi, tetapi juga peningkatan jumlah pengangguran dalam skala besar (Nurwati, 2020). virus ini biasanya pertama kali menyerang dan menginfeksi paru-paru dan jaringan saluran pernapasan, dalam kasus ekstrim, hampir semua organ utama dalam tubuh sekarang diketahui terkena dampak negatif yang sering menyebabkan kegagalan sistemik yang parah pada beberapa orang (Woods et al., 2020). Peningkatan kasus Covid-19 di seluruh dunia menjadi bahan pemikiran bagi setiap kepala negara dunia untuk dapat mengantisipasi bahaya selanjutnya, seperti permasalahan ekonomi,(Carlsson-Szlezak, Reeves, \& Swartz, 2020) sosial, budaya, keamanan, dan politik. Khususnya pemerintah Indonesia yang telah mengadakan strategi untuk mengadaptasi bencana nasional yang bersifat makro, diantaranya memodifikasi kebijakan karantina wilayah (lockdown) menjadi pembatasan sosial berskala besar (PSBB) yang bersifat lokal sesuai tingkat keparahan di wilayah provinsi, kabupaten, atau kota. Selama masa pandemi ini, perekonomian dunia dan Indonesia mengalami pelambatan. Pemerintah dan lembaga kajian strategis memprediksi Indonesia tumbuh rendah atau bahkan negatif di tahun 2020. :(“Covid-19, New Normal, dan Perencanaan Pembangunan di Indonesia," 2020) Pandemi Covid-19 melanda dunia, dan Indonesia termasuk di dalamnya. Indonesia berjuang melaw an Covid-19 dengan. Selain itu, pandemi Covid-19 memberikan dampak yang parah terhadap sektor pariwisata, setelah sebelumnya sektor ini mengalami serangan wabah serupa dan berbagai cobaan lain namun dapat bangkit kembali. Pandemi Covid-19 berdampak lebih berat (Sugihamretha, 2020), ketakutan ini berdampak pada industri pariwisata dalam negeri dan internasional. Maskapai penerbangan telah membatalkan semua penerbangan dan perencanaan lainnya yang berhubungan dengan akomodasi (Hoque, Shikha, Hasanat, Arif, \& Abu Bakar Abdul Hamid, 2020). Seperti yang telah kita ketahui dalam pertandingan liga 1 Shopee 2020/2021 yang merupakan sajian atau kolaborasi antara industri olahraga dengan pariwisata, pada saat ini secara umum diakui bahwa olahraga adalah industri yang menyumbang bagian signifikan dari Produk Domestik Bruto, pengeluaran konsumen, dan pekerjaan di suatu negara(Wilson, 2016), salah satu contohnya adalah data terakhir dari perhelatan sebuah pertandingan liga Indonesia pada tahun 2017 dapat menyerap 1.213.805 yang datang langsung ke stadion untuk menyaksikan pertandingan secara langsung, jumlah penonton laga pembuka Persib Bandung-Arema FC masih yang 
terbanyak. laga itu. dihadiri total penonton 34.150 (Liga Indonesia, 2017). Namun semenjak adanya Pandemic Covid-19, setiap stadion dan kegiatan olahraga yang menyerap kerumunan banyak orang dihentikan atas dasar untuk mencegah penyebaran. Berikut ini adalah grafik mengenai kasus harian Covid-19 di Indonesia:

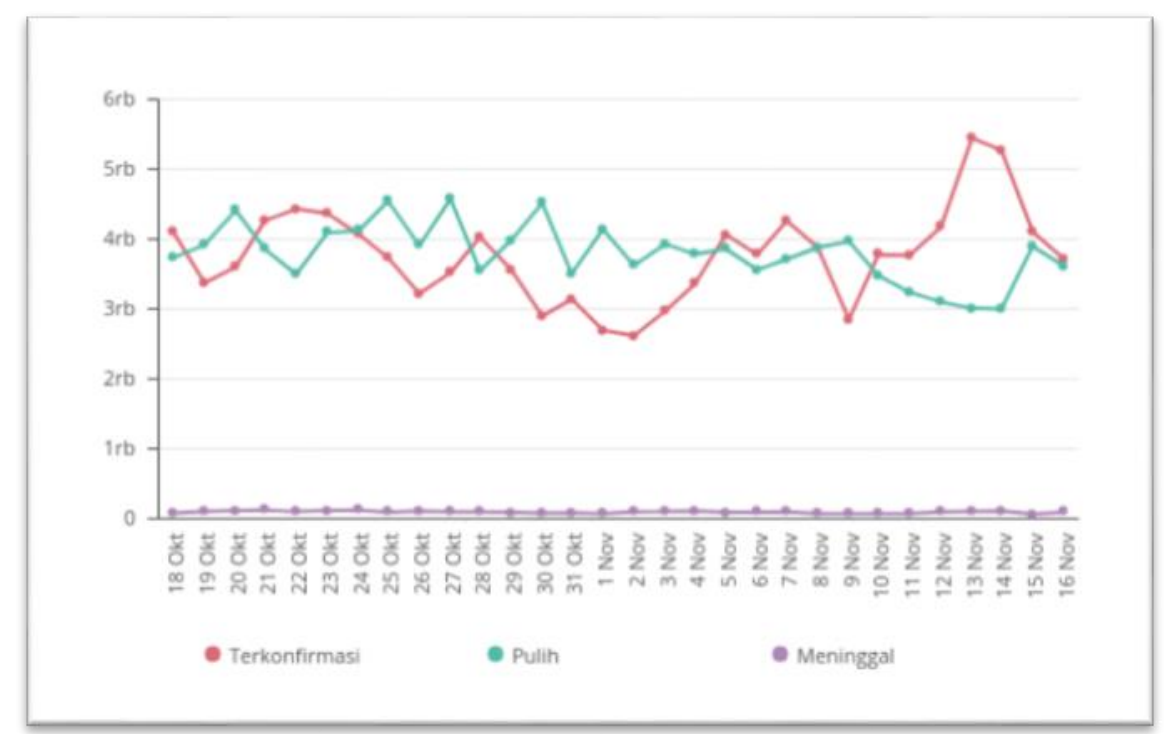

\section{Gambar 1. Grafik kasus harian covid-19 Indonesia (Diupdate pada tanggal 16 November 2020) Sumber : Covid19.go.id}

Dari hari kehari, peningkatan kasus yang terkonfirmasi semakin meningkat, hal diatas menjadi pelajaran kepada masyarakat untuk tetap menjaga protokoler kesehatan, walaupun harus berkerja mencari dan memenuhi kebutuhan hidup (Ridwan, 2016).

Dari hari kehari, peningkatan kasus yang terkonfirmasi semakin meningkat, hal diatas menjadi pelajaran kepada masyarakat untuk tetap menjaga protokoler kesehatan, walaupun harus berkerja menc ari dan memenuhi kebutuhan hidup (Ridw an, 2016).

Kasus positif Covid-19 di Indonesia bertambah lagi sebanyak 3.718 kasus, hingga Senin, 16 November 2020. Total pengidap virus korona baru mencapai 470.648 orang. 395.443 orang di antaranya pulih, dan 15.296 orang meninggal dunia, dengan adanya data diatas kemungkinan untuk mengadakan atau menggelar kembali lanjutan kompetisi liga 1 Shopee 2020/2021 akan sulit terealisasi, sehingga akan berdampak terhadap tingkat penghasilan yang didapatkan oleh wasit dan asisten wasit liga 1. Sebagaimana diuraikan di bawah ini : 
Tabel 1. Penghasilan wasit

\begin{tabular}{|c|c|c|c|c|c|c|c|}
\hline No & Nama & Umur & Status & $\begin{array}{l}\text { Pekerjaan } \\
\text { lain }\end{array}$ & $\begin{array}{c}\text { Penghasilan } \\
\text { Sebelum } \\
\text { Covid-19 }\end{array}$ & $\begin{array}{c}\text { Penghasilan } \\
\text { pada masa } \\
\text { Covid-19 }\end{array}$ & $\begin{array}{c}\text { Alternatif untuk } \\
\text { mempertahankan } \\
\text { keberlangsungan } \\
\text { hidup }\end{array}$ \\
\hline 1 & TMA & 32 & Menikah & Tidak ada & $>4$ juta & $<1$ juta & Kreatif \\
\hline 2 & AY & 36 & Menikah & Wiraswasta & $>4$ juta & $<1$ juta & $\begin{array}{l}\text { Berjualan nasi uduk. } \\
\& \text { toko beras }\end{array}$ \\
\hline 3 & YN & 34 & Menikah & Dosen & $>4$ juta & $\begin{array}{l}\text { Tidak ada } \\
\text { penghasilan }\end{array}$ & bekerja \\
\hline 4 & NR & 37 & Menikah & GURU & $>4$ juta & $\begin{array}{l}\text { Tidak ada } \\
\text { penghasilan }\end{array}$ & Gaji Guru \\
\hline 5 & GRL & 37 & Menikah & Guru & $>4$ juta & $<500$ ribu & $\begin{array}{l}\text { Mencari penghasilan } \\
\text { dari bidang lain }\end{array}$ \\
\hline 6 & $\mathrm{AA}$ & 33 & Menikah & Guru & $>4$ juta & $\begin{array}{l}\text { Tidak ada } \\
\text { penghasilan }\end{array}$ & $\begin{array}{l}\text { Dari gaji sebagai } \\
\text { guru }\end{array}$ \\
\hline & Asister & wasit & & & & & \\
\hline 1 & BS & 33 & Menikah & Dosen & $>4$ juta & $\begin{array}{l}\text { Tidak ada } \\
\text { penghasilan }\end{array}$ & Fokus bekerja \\
\hline 2 & DS & 38 & Menikah & Berdagang & $>4$ juta & $<500$ ribu & $\begin{array}{l}\text { Wiraswasta } \\
\text { berjualan lotek }\end{array}$ \\
\hline 3 & $\mathrm{DL}$ & 37 & Menikah & Tidak ada & $>4$ juta & $\begin{array}{l}\text { Tidak ada } \\
\text { penghasilan }\end{array}$ & Cari usaha lain \\
\hline 4 & AS & 44 & Menikah & Dagang & $>4$ juta & $\begin{array}{l}\text { Tidak ada } \\
\text { penghasilan }\end{array}$ & $\begin{array}{l}\text { Menghemat } \\
\text { sehemat hematnya }\end{array}$ \\
\hline 5 & AFR & 35 & Menikah & Tidak ada & $>4$ juta & $<500$ ribu & Memakai tabungan \\
\hline
\end{tabular}

Dari data diatas penghasilan para wasit dan asisten wasit sebelum masa Pandemi Covid-19 lebih dari Rp.4.000.000 menyamai dari Upah Minimum Regional (UMR) tertinggi di Indonesia yakni Provinsi DKI Jakarta dengan angka Rp. Rp4.267.349,00 (https://gajimu.com/gaji/gaji-minimum), sesuai dengan data yang ada sebelum masa pandemic Covid-19, $100 \%$ wasit dan asisten wasit mendapatkan penghasilan yang layak, akan tetapi pada masa pandemic Covid-19,terdapat 2 orang wasit yang mempunyai penghasilan di bawah Rp. 1.000.000, 3 orang berpenghasilan kurang dari Rp.500.000, kemudian 6 orang yang tidak memiliki penghasilan yang berasal dari wasit.

Sedangkan hasil dari wawancara dan survey dari aplikasi surveyheart, memaparkan bahwa usaha dan pemikiran kreatif (Runco, 2016) harus dikedepankan untuk mencari solusi agar pendapatan dapat memenuhi kebutuhan hidup keluarga,baik dengan membuka usaha dengan berdagang, kreativitas memainkan peran penting dalam inovasi, kemajuan teknologi, dan evolusi masyarakat dalam peningkatan kualitas ekonomi, bekerja bagi yang memiliki pekerjaan tetap, mempergunakan tabungan dengan seefektif dan seefisien mungkin.

\section{KESIMPULAN}

Dapat disimpulkan bahwa tujuan utama dari analisis ini adalah menganalisis dampak ekonomi langsung yang dialami oleh wasit dan asisten wasit sepakbola Liga 1 
Shopee 2020/2021 di lingkungan Asosisasi Provinsi PSSI Jawa Barat. Sebelum terjadinya pandemi, wasit dan asisten wasit memiliki penghasilan yang melebihi dari standar Upah Minimum Regional (UMR) provinsi DKI Jakarta, yang notabene menjadi provinsi dengan UMR tertinggi di Indonesia. Hasil analisis menyimpulkan bahwa, kebijakan pemerintah dan PSSI beserta PT Liga Indonesia Baru untuk menghentikan sementara dengan waktu yang belum bisa ditentukan mengenai kepastian waktu untuk dilanjutkan kembali dalam gelaran Liga 1 Shopee 2020/2021, berimbas kepada tingkat kesejahteraan dan pendapatan wasit beserta asisten wasit. Akan tetapi, kesimpulan ini hanya bersifat variabel bebas yaitu variable yang berhubungan dengan pendapatan. Dapat disimpulkan kembali bahwa kerugian yang dialami sekarang ini dibutuhkan kerjasama dan pengorbanan disertai dengan kedisiplinan seluruh lapisan masyarakat untuk selalu menerapkan protokoler kesehatan yang dikonversi menjadi kebiasaan dan budaya agar terhindar dari Covid-19. Dampak wabah Covid-19 menimbukan masalah sosial pelemahan ekonomi masyarakat dan negara, Untuk mencegah penyebaran wabah Covid19 diperlukan kerjasama pemerintah, masyarakat, tokoh agama untuk saling bantu membatu, bahu membahu dan mengingatkan satu sama lainnya bersama melaw an Covid19 (Syafrida, 2020).

\section{DAFTAR PUSTAKA}

Ambarwati, R. (2017). Tidur, Irama Sirkadian dan Metabolisme Tubuh. Jurnal Keperawatan.

Carlsson-Szlezak, P., Reeves, M., \& Swartz, P. (2020). What coronavirus could mean for the global economy. Harvard Business Review.

Covid-19, New Normal, dan Perencanaan Pembangunan di Indonesia. (2020). Jurnal Perencanaan Pembangunan: The Indonesian Journal of Development Planning. https://doi.org/10.36574/jpp.v4i2.118

Hanoatubun, S. (2020). Dampak COVID-19 Terhadap Perekonomian Indonesia. Journal of Education, Psychology and Counseling.

Hoque, A., Shikha, F. A., Hasanat, M. W., Arif, I., \& Abu Bakar Abdul Hamid. (2020). The Effect of Coronavirus ( COVID-19) in the Tourism Industry in. Asian Journal of Multidisciplinary Studies.

Laerd Dissertation. (2012). Total population sampling.

Liga Indonesia. (2017). Serap 1,2 Juta Penonton, Laga Persija Terdepan. PT. Liga Indonesia.

Nadiar, F., \& Janitra, J. (2020). OLAHRAGA DAN COVID-19. Olahraga Dan Covid19.

Nia Novita Wiraw an. (2017). Indonesian Journal of Human Nutrition. Indonesian Journal of Human Nutrition. https://doi.org/10.21776/ub.ijhn.2016.003.Suplemen.5

Nurwati, R. A. M. dan R. N. (2020). Dampak Pandemi Covid-19 Terhadap Peningkatan 
Angka Pengangguran di Indonesia. Rahma Ainul Mardiyah R. Nunung Nurwati.

Palar, C. M., Wongkar, D., \& Ticoalu, S. H. R. (2015). MANFAAT LATIHAN OLAHRAGA AEROBIK TERHADAP KEBUGARAN FISIK MANUSIA. Jurnal E-Biomedik. https://doi.org/10.35790/ebm.3.1.2015.7127

Pane, B. S. (2015). Peranan Olahraga Dalam Meningkatkan Kesehatan. Jurnal Pengabdian Kepada Masyarakat.

Prasetyo, Y. (2015). KESADARAN MASYARAKAT BEROLAHRAGA UNTUK PENINGKAT AN KESEHATAN DAN PEMBANGUNAN NASIONAL. MEDIKORA. https://doi.org/10.21831/medikora.v11i2.2819

Ridwan, I. R. (2016). DAMPAK INDUSTRI TERHADAP LINGKUNGAN DAN SOSIAL. Jurnal Geografi Gea. https://doi.org/10.17509/gea.v7i2.1716

Runco, M. A. (2016). Creativity. In The Curated Reference Collection in Neuroscience and Biobehavioral Psychology. https://doi.org/10.1016/B978-0-12-809324-5.03042$\mathrm{X}$

Sugihamretha, I. D. G. (2020). Respon Kebijakan: Mitigasi Dampak Wabah Covid-19 Pada Sektor Pariwisata. Jurnal Perencanaan Pembangunan: The Indonesian Journal of Development Planning. https://doi.org/10.36574/jpp.v4i2.113

Syafrida, S. (2020). Bersama Melawan Virus Covid 19 di Indonesia. SALAM: Jurnal Sosial Dan Budaya Syar-I. https://doi.org/10.15408/sjsbs.v7i6.15325

Tangkudung James. (2006). Kepelatihan Olahraga "Pembinaan Prestasi Olahraga." Jakarta: Cerdas Jaya.

Wilson, R. (2016). Economics of sport and recreation. Annals of Leisure Research. https://doi.org/10.1080/11745398.2015.1053706

Woods, J. A., Hutchinson, N. T., Powers, S. K., Roberts, W. O., Gomez-Cabrera, M. C., Radak, Z., ... Ji, L. L. (2020). The COVID-19 pandemic and physical activity. Sports Medicine and Health Science. https://doi.org/10.1016/j.smhs.2020.05.006

Zendrato, W. (2020). Gerakan Mencegah Daripada Mengobati Terhadap Pandemi Covid19. Jurnal Education and Development.

Website:

Covid19.go.id

lifestyle.kompas.com

(https://gajimu.com/gaji/gaji-minimum),

(www.kompas.com) 